\title{
Osthole induces G2/M arrest and apoptosis in lung cancer A549 cells by modulating PI3K/Akt pathway
}

Xiaoman Xu', Yi Zhang ${ }^{2}$, Dan Qu', Tingshu Jiang ${ }^{1}$ and Shengqi Li ${ }^{1 *}$

\begin{abstract}
Background: To explore the effects of Osthole on the proliferation, cell cycle and apoptosis of human lung cancer A549 cells.

Methods: Human lung cancer A549 cells were treated with Osthole at different concentrations. Cell proliferation was measured using the MTT assay. Cell cycle was evaluated using DNA flow cytometry analysis. Induction of apoptosis was determined by flow cytometry and fluorescent microscopy. The expressions of Cyclin B1, p-Cdc2, BCl-2, Bax, t-Akt and p-Akt were evaluated by Western blotting.

Results: Osthole inhibited the growth of human lung cancer A549 cells by inducing G2/M arrest and apoptosis. Western blotting demonstrated that Osthole down-regulated the expressions of Cyclin B1, p-Cdc2 and Bcl-2 and up-regulated the expressions of Bax in A549 cells. Inhibition of PI3K/Akt signaling pathway was also observed after treating A549 cells with Osthole.
\end{abstract}

Conclusions: Our findings suggest that Osthole may have a therapeutic application in the treatment of human lung cancer.

\section{Background}

Lung cancer is the leading cause of cancer-related death in the world, and non-small cell lung cancer accounts for approximately $80 \%$ of all cases [1,2]. Despite advances in diagnostic and therapeutic, the overall 5 -year survival rate in many countries is generally less than $15 \%$ [3]. In order to improve the survival rate, intensive efforts have been made to find new anticancer agents, and many attentions have been drawn to herbal medicines owing to their wide range of biological activities, low toxicity and side effects [4-6].

Osthole, 7-methoxy-8-(3-methyl-2-butenyl)coumarin (Figure 1), is an active constituent of Cnidium monnieri (L.) Cusson, has been extracted from many medicinal plants such as Cnidium monnieri and other plants. Osthole has long been used in traditional Chinese medicine for the treatment of eczema, cutaneous pruritus, trichomonas vaginalis infection, and sexual dysfunction.

\footnotetext{
* Correspondence: shengqi-li@hotmail.com

'Department of Respiratory Medicine, the Shengjing Hospital, China Medical University, Shenyang 110004, PR China

Full list of author information is available at the end of the article
}

Recent studies have revealed that Osthole may have antiproliferative [7], vasorelaxant [8], anti-inflammatory [9], antimicrobacterial [10], antiallergic [11], and preventing prophylactic effects in hepatitis [12]. Furthermore, the anticancer effect of Osthole has been reported in few papers [13-17]. These studies have revealed that Osthole inhibited the growth, invasion and metastasis of cancer cells. However, the effects of Osthole on human lung cancer cells remain unclear.

The PI3K/Akt signaling pathway is a critical transduction pathway which plays an important role in regulating cell proliferation, cell cycle and apoptosis [18]. Various types of cancer, including lung cancer, were reported to aberrantly activate this pathway [19]. Recent studies have shown that some anticancer-drugs could induce G2/M arrest accompanying the down-regulation of Akt [20,21]. And the PI3K/Akt pathway participates in the regulation of Bcl-2 family proteins, which are key regulators of the apoptotic pathway [22]. In the present study, we observed that Osthole induces $\mathrm{G} 2 / \mathrm{M}$ arrest and apoptosis in lung cancer A549 cells. Osthole-induced G2/M arrest and apoptosis were associated with inhibition of the Cyclin
() Biomed Central

(ㄷ) 2011 Xu et al; licensee BioMed Central Ltd. This is an Open Access article distributed under the terms of the Creative Commons Attribution License (http://creativecommons.org/licenses/by/2.0), which permits unrestricted use, distribution, and reproduction in any medium, provided the original work is properly cited. 


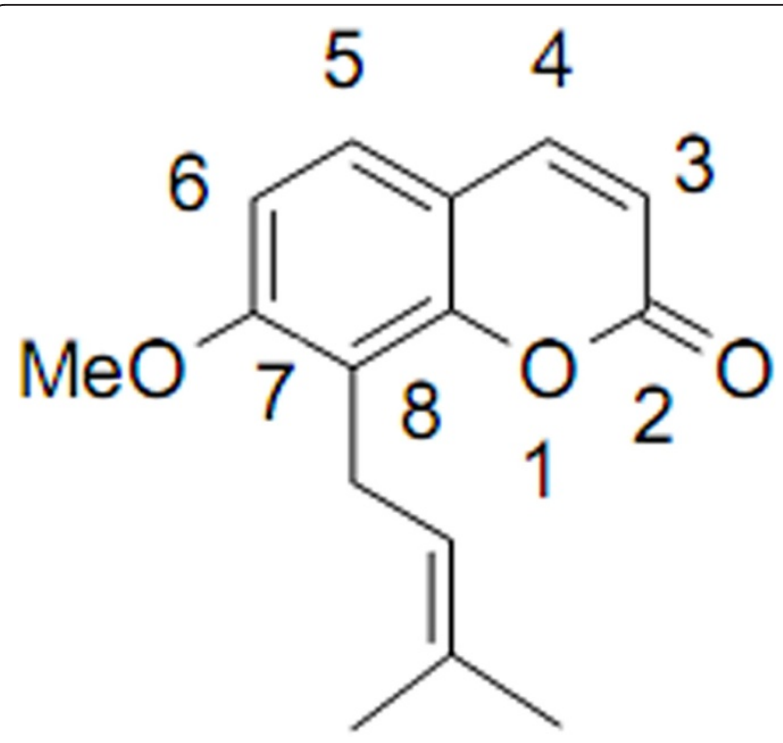

Figure 1 The structure of Osthole

B1, p-Cdc2 and p-Akt expressions, and up-regulation of the ratio of $\mathrm{Bax} / \mathrm{Bcl}-2$ proteins.

\section{Methods \\ Reagents}

RPMI-1640, trypsin, penicillin and streptomycin were purchased from Biological Industries (Kibutz Beit Haemek, Israel). Fetal bovine serum (FBS) was purchased from Solarbio Science\&Technology (Beijing, China). 3-(4, 5-dimethyl thiazol-2yl)-2, 5-diphenyltetrazolium bromide (MTT), dimethyl sulfoxide (DMSO), Propidium iodide (PI), and Hoechst 33342 were purchased from Sigma-Aldrich (St. Louis, USA). Annexin V-FITC and PI double staining kit were purchased from Key Gene (Nanjing, China). Osthole was purchased from the National Institute for the control of Pharmaceutical and biological products (Beijing, China), a $50 \mathrm{mM}$ stock solution of Osthole was dissolved in DMSO and stored at $-20^{\circ} \mathrm{C}$. Antibodies were purchased from Santa Cruz Biotechnology (Santa Cruz, CA). All other reagents were procured locally.

\section{Cell line and culture conditions}

The human lung cancer cell line A549 was obtained from the China Center for Type Culture Collection (Wuhan, China) and maintained in RPMI-1640 supplemented with $10 \% \mathrm{FBS}, 100 \mathrm{U} / \mathrm{ml}$ penicillin, and $100 \mu \mathrm{g} /$ $\mathrm{ml}$ streptomycin at $37^{\circ} \mathrm{C}$ in a humidified atmosphere of $5 \%$ CO2.

\section{MTT Assay}

Cell proliferation was measured using the MTT assay. A549 cells were plated at a density of $1 \times 10^{4}$ cells per well in 96-well plates overnight and then treated with different concentrations of Osthole $(0,25,50,100,150$, and $200 \mu \mathrm{M})$. After 24, 48 and $72 \mathrm{~h}$ treatment, $20 \mu \mathrm{l}$ of MTT solution (2 $\mathrm{mg} / \mathrm{ml}$ in PBS) were added to each well and the cells were cultured for another $4 \mathrm{~h}$ at $37^{\circ} \mathrm{C}$. Then the medium was totally removed and $150 \mu \mathrm{l}$ DMSO was added to solubilize MTT formazan crystals. Finally, the plates were shaken and the optical density was determined at $570 \mathrm{~nm}$ (OD570) using a ELISA plate reader (Model 550, Bio-Rad, USA). At least three independent experiments were performed.

\section{Cell cycle analysis}

Cell cycle was evaluated using DNA flow cytometry analysis. A549 cells were plated at a density of $1 \times 10^{6}$ cells per well in 6-well plates overnight and then treated with different concentrations of Osthole $(0,50,100,150 \mu \mathrm{M})$. After $48 \mathrm{~h}$ treatment, the cells were harvested and washed twice with PBS, then centrifuged at $1200 \times \mathrm{g}$ for 5 min, fixed in $70 \%$ ethanol at $4^{\circ} \mathrm{C}$. Before flow cytometry analysis, the cells were washed again with PBS, treated with RNase $(50 \mu \mathrm{g} / \mathrm{ml})$, and stained with PI $(100 \mu \mathrm{g} /$ $\mathrm{ml}$ ) in the dark for $30 \mathrm{~min}$. The samples were analyzed by FACScan flow cytometer (Becton Dickinson, San Jose, CA).

\section{Annexin V/PI flow cytometry analysis}

Apoptotic rates were determined by flow cytometry analysis using an Annexin V-FITC Apoptosis Kit. A549 cells were plated at a density of $1 \times 10^{6}$ cells per well in 6 -well plates overnight and then treated with different concentrations of Osthole $(0,50,100,150 \mu \mathrm{M})$ for $48 \mathrm{~h}$. Staining was performed according to the manufacturer's instructions, and flow cytometry was conducted on a FACScan flow cytometer (Becton Dickinson, San Jose, $\mathrm{CA})$. The percentage of the early apoptosis was calculated by annexin V-positivity and PI-negativity, while the percentage of the late apoptosis was calculated by annexin V-positivity and PI-positivity.

\section{Fluorescent microscopy}

A549 cells were treated with different concentrations of Osthole $(0,50,100$, and $150 \mu \mathrm{M})$ for $48 \mathrm{~h}$. Cells were washed twice with PBS and fixed with cold methanol and acetic acid $(3 / 1, \mathrm{v} / \mathrm{v})$ before being stained with Hoechst $33342(1 \mathrm{mg} / \mathrm{ml})$ for $30 \mathrm{~min}$ at $37^{\circ} \mathrm{C}$. Stained cells were observed with a fluorescence microscope (×400, Nikon, Japan).

\section{Western blotting analysis}

The expression of cellular proteins was evaluated by Western blotting. After treatment for $48 \mathrm{~h}$, the cells were washed twice with ice-cold PBS. The total proteins were solubilized and extracted with lysis buffer $(20 \mathrm{mM}$ 
HEPES, pH 7.9, 20\% glycerol, $200 \mathrm{mM} \mathrm{KCl,} 0.5 \mathrm{mM}$ EDTA, 0.5\% NP40, $0.5 \mathrm{mM}$ DTT, 1\% protease inhibitor cocktail). Protein concentration was determined by bicinchoninic acid (BCA) protein assay. Equal amounts of protein $(50 \mu \mathrm{g})$ from each sample were subjected to seperate on a SDS-PAGE. After electrophoresis, proteins were electroblotted to polyvinylidene difluoride membranes. The membranes were blocked at room temperature and then incubated at $4^{\circ} \mathrm{C}$ overnight with the first antibodies of Cyclin B1, p-Cdc2, Bcl-2, Bax, t-Akt and p-Akt seperately. After being washed three times with TBST(20 mM Tris-Cl, pH 7.5, $150 \mathrm{mM} \mathrm{NaCl}, 1 \mathrm{~g} / \mathrm{L}$ Tween20), membranes were incubated with secondary antibodies. After incubation, the membranes were washed three times with TBST, and visualization was made using an ECL kit.

\section{Statistical analysis}

The data are expressed as mean \pm SD. Statistical correlation of data was checked for significance by ANOVA and Student's $t$ test. Differences with $\mathrm{P}<0.05$ were considered significant. These analyses were performed using SPSS 11.0 software.

\section{Results}

\section{Osthole inhibited A549 cell proliferation}

To investigate the growth inhibition effects of Osthole, the cells were treated with different concentrations of Osthole for 24, 48 and $72 \mathrm{~h}$, and the rate of inhibition was determined by MTT assay. We observed that growth of A549 cells was suppressed in a dose- and time-dependent manner(Figure 2).

\section{Osthole induces $\mathrm{G}$ 2/M arrest}

To determine whether Osthole inhibits the cell cycle progression of A549 cells, the cells were treated with different concentrations of Osthole $(0,50,100$, and $150 \mu \mathrm{M})$ for $48 \mathrm{~h}$ and the cell cycle distribution was analyzed by flow cytometry. As shown in Figure 3, the

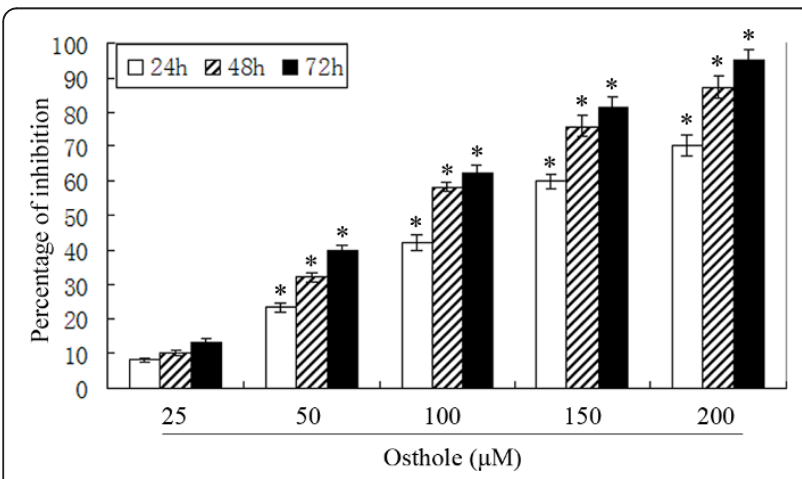

Figure 2 The proliferative inhibition effects of Osthole on human lung cancer A549 cells. ${ }^{*} p<0.001$ versus control group.
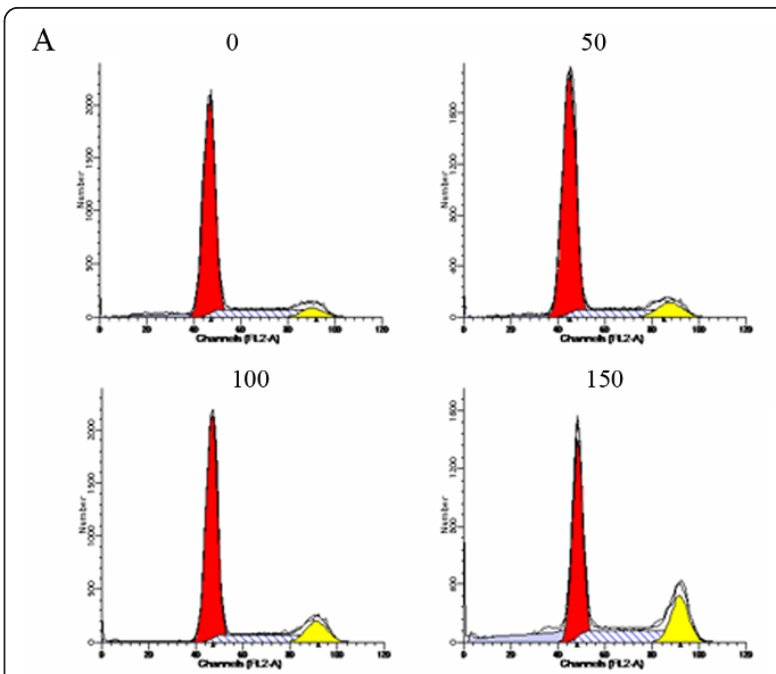

B

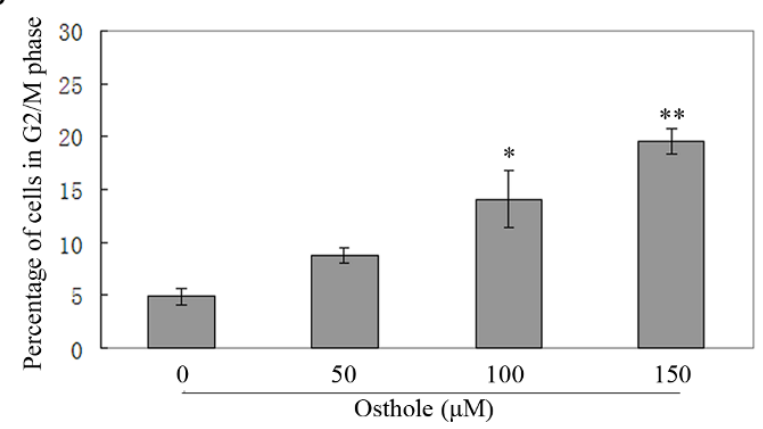

Figure 3 Cell cycle distribution analysis by DNA flow cytometry. (A) A549 cells were treated with $(0,50,100$ and 150 $\mu \mathrm{M})$ Osthole for $48 \mathrm{~h}$. Then the cells were harvested and treated with RNase, stained with PI. The cell cycle distribution was analyzed by flow cytometry. (B) The percentage of cells in G2/M phase in histograms. ${ }^{*} p<0.01$, ${ }^{* *} p<0.001$ versus control group.

percentage of cells in $\mathrm{G} 2 / \mathrm{M}$ phase with Osthole treatment were $4.9 \%, 8.8 \%, 14.1 \%$ and $19.5 \%$ after $48 \mathrm{~h}$, respectively.

\section{Osthole induces the apoptosis of A549 cells}

A549 cells were treated with different concentrations of Osthole $(0,50,100$, and $150 \mu \mathrm{M})$ for $48 \mathrm{~h}$ and were analyzed by flow cytometry. As showed in Figure 4A, B, the numbers of early and late apoptotic cells were significantly increased compared to control group. The proportion of early and late apoptotic cells in the $150 \mu \mathrm{M}$ treatment group was about six times higher than in the drug-free group. The proportion of apoptotic cells in treated cells were increased in a dose-dependent manner.

After incubation with different concentrations of Osthole $(0,50,100$, and $150 \mu \mathrm{M})$ for $48 \mathrm{~h}$, the cells were examined by fluorescent microscopy analysis. As shown in Figure $4 \mathrm{C}$, condensation of chromatin, nuclear 


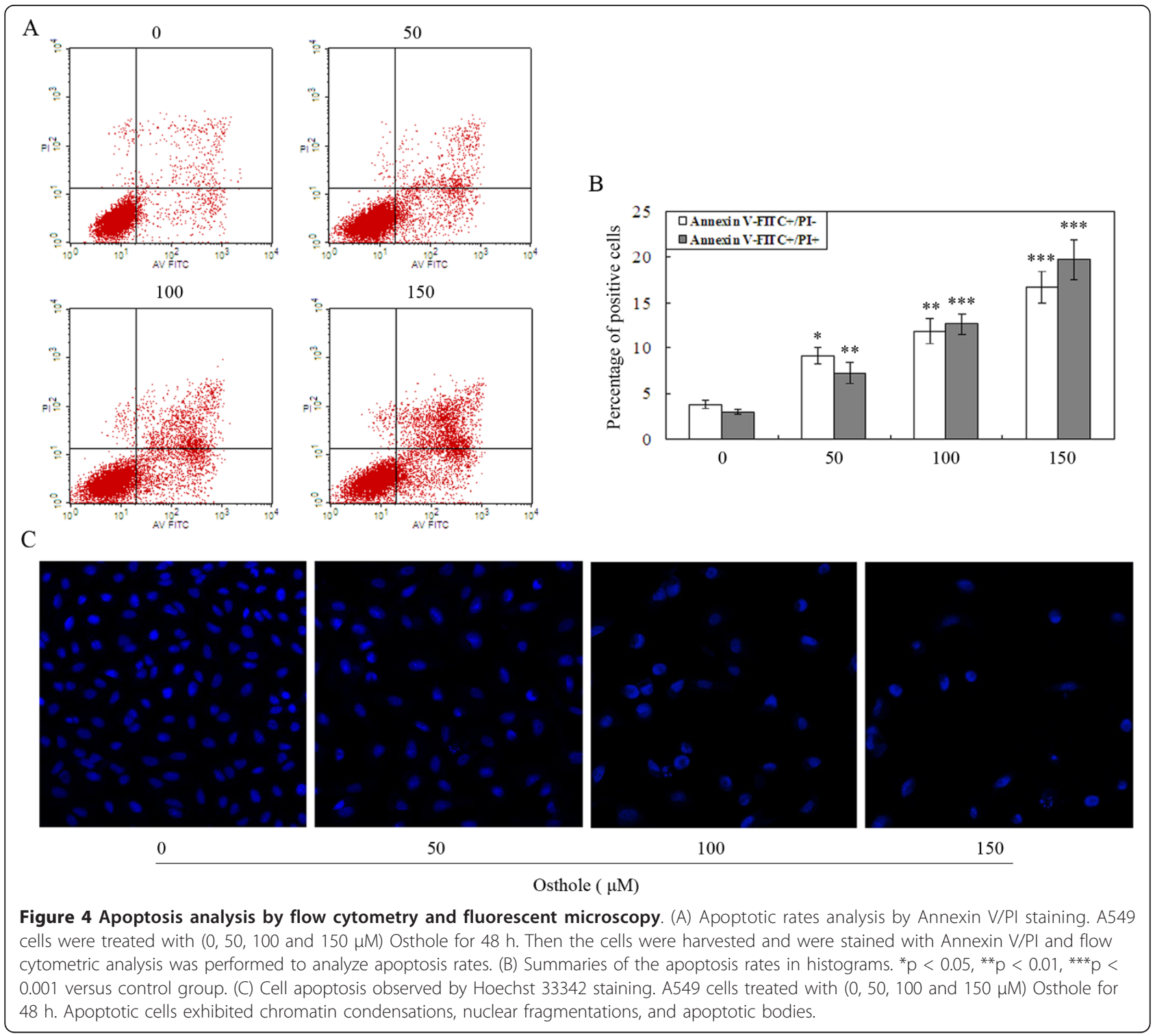

fragmentations and apoptotic bodies were found clearly in treated cells. The results showed that when exposed to Osthole, A549 cells underwent the typical morphologic changes of apoptosis in a dose-dependent manner.

\section{Osthole decreases Cyclin B1 and p-Cdc2 expressions}

To investigate the mechanism underlying cell cycle arrest induced by Osthole, we tested the effect of this compound on p-Cdc2, Cyclin B1 levels. As shown in Figure 5, Western blotting analysis revealed that Osthole decreased the protein levels of Cyclin B1 and p-Cdc2 via a dose-dependent manner.

Effect of Osthole on expressions of Bcl-2 family proteins To investigate the mechanism underlying apoptosis induced by Osthole, we tested the effect of this

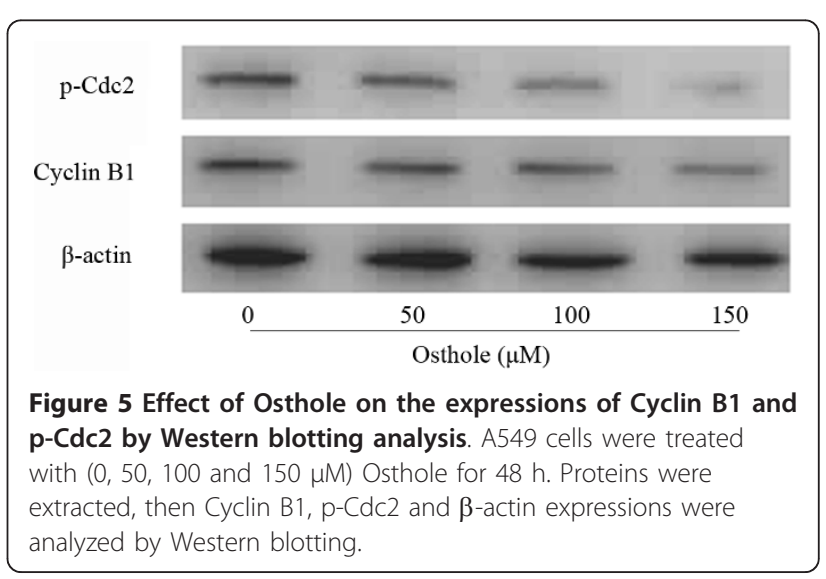


compound on Bcl-2, Bax levels. As shown in Figure 6, Western blotting analysis revealed that Osthole treatment leads to decrease in Bcl-2 levels and increase in Bax levels as compared to control cells. These results indicated that Osthole up-regulation of the $\mathrm{Bax} / \mathrm{Bcl}-2$ ratio in a dose-dependent manner.

\section{Effects of Osthole on PI3K/Akt pathway}

In order to better understand the molecular basis of Osthole induced G2/M arrest and apoptosis, we investigated the expression of p-Akt and t-Akt after treatment with Osthole $(0,50,100$, and $150 \mu \mathrm{M})$ for $48 \mathrm{~h}$. As shown in Figure 7, the levels of p-Akt are dose-dependently decreased in response to Osthole, while the total Akt protein levels remained constant during Osthole treatment.

\section{Discussion}

Osthole, an active constituent of Cnidium monnieri (L.) Cusson, extracted from many medicinal plants and herbs such as Cnidium monnieri, Angelica pubescens and some species of Leguminosae and Compositae. Osthole has been shown to have comprehensive and wider applications as anti-hepatitis, anti-oxidation, anti-inflammatory, anti-microbacterial, and antiallergic effects [7-12]. Furthermore, the anticancer effect of Osthole has been reported in a few papers. Both in vitro and in vivo studies showed that Osthole possessed an anticancer effect by inhibiting human cancer cells growth and inducing apoptosis [13-17]. It is reported recently that Osthole is able to inhibit the migration and invasion of breast cancer cells [15]. Osthole may be a good compound for developing anticancer drugs.

The induction of cell cycle arrest and apoptosis are common mechanisms proposed for the cytotoxic effects of anticancer-drug extracted from herbal medicine [23]. Cell cycle arrest can trigger proliferation inhibition and apoptosis in cancer cells $[24,25]$. During cell cycle, the G2/M checkpoint is a potential target for cancer therapy. It prevents DNA-damaged cells from entering

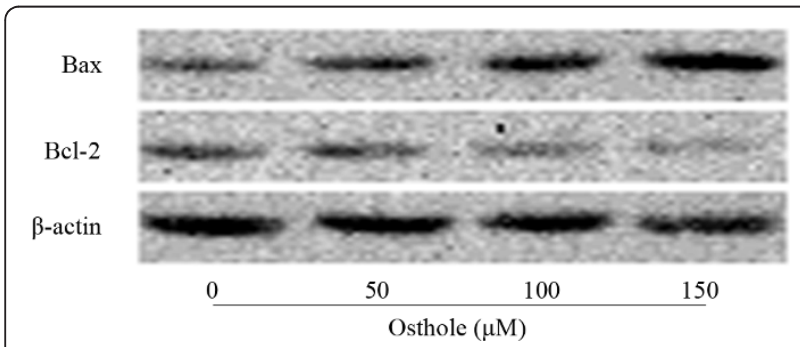

Figure 6 Effect of Osthole on Bcl-2 family proteins by Western blotting analysis. A549 cells were treated with (0, 50, 100 and $150 \mu \mathrm{M})$ Osthole for $48 \mathrm{~h}$. Proteins were extracted, then Bax, Bcl-2 and $\beta$-actin expressions were analyzed by Western blotting.

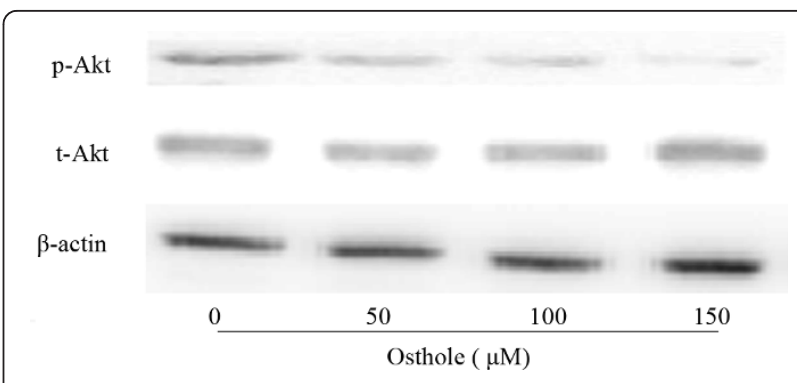

Figure 7 Effect of Osthole on the PI3K/Akt signaling pathways by Western blotting analysis. A549 cells were treated with $(0,50$, 100 and $150 \mu \mathrm{M})$ Osthole for $48 \mathrm{~h}$. Proteins were extracted, then $\mathrm{p}$-Akt, t-Akt and $\beta$-actin expressions were analyzed by Western blotting.

mitosis and allows for the repair of DNA that was damaged in late $S$ or G 2 phases prior to mitosis [26]. The G2/M checkpoint is controlled by Cdc2 and Cyclin B1 [27], and some anticancer-drugs could induce G2/M arrest through down-regulating the expressions of Cyclin B1 and Cdc2 [28]. The results in our study showed that treating A549 cells with Osthole resulted in decreased expression of $\mathrm{Cdc} 2$ and Cyclin B1, suggesting that decreasing of $\mathrm{Cdc} 2$ and Cyclin $\mathrm{B} 1$ expression might be the molecular mechanism through which Osthole induced G2/M arrest.

Apoptosis, an important regulator in developmental processes, maintenance of homeostasis and elimination of the damaged cells, is the outcome of a complex interaction between pro- and anti-apoptotic molecules. Proteins of the Bcl-2 family are key regulators of the apoptotic pathway [29,30]. Bcl-2 family can be divided into two subfamilies: one is anti-apoptotic protein such as Bcl-2, the other is pro-apoptotic protein such as Bax. Accumulated data have shown that many anticancer agents induced apoptosis by targeting the proteins of $\mathrm{Bcl}-2$ family and the ratio of $\mathrm{Bax} / \mathrm{Bcl}-2$ played a critical role in determining whether cells will undergo apoptosis $[31,32]$. In our study, by examining the effect of Osthole on Bax and Bcl-2, we found that Osthole increased proapoptotic Bax expression and decreased anti-apoptotic $\mathrm{Bcl}-2$ expression, leading to up-regulation of the ratio of $\mathrm{Bax} / \mathrm{Bcl}-2$. This might be one of the molecular mechanisms through which Osthole induces apoptosis.

The PI3K/Akt is one of the most important signaling pathways in regulating cell growth, proliferation and apoptosis, and Akt is a major downstream target of PI3K [18]. The PI3K/Akt signaling pathway regulates the development and progression of various cancers by elevating the activity of the anti-apoptotic action of Akt, and the phosphorylation of Akt is routinely used as readout for the Akt activation [33]. In our study, we evaluated the effect of Osthole on the PI3K/Akt 
pathways by measuring the protein expression levels of total Akt and phospho-Akt protein. We found that treatment of A549 cells with Osthole reduced the protein expression of p-Akt in a dose-dependent manner, while the total Akt protein levels remained constant during Osthole treatment. Recently studies have shown that some anticancer-drugs could induce G2/M arrest and apoptosis accompanying down-regulation of Akt [20-22]. Meanwhile, we also found that Osthole treatment down-regulated $\mathrm{Cdc} 2 / \mathrm{Cyclin} \mathrm{B} 1, \mathrm{Bcl}-2$ protein and up-regulated Bax in our study. In summary, these results indicated that Osthole induced G2/M arrest and apoptosis possibly by down-regulating Akt signaling in human lung cancer A549 cells.

\section{Conclusions}

Our studies demonstrated that Osthole inhibited the growth of human lung cancer A549 cells by inducing G2/M arrest and apoptosis. This might be the important mechanisms of Osthole suppressed the growth of the lung cancer cells. Our findings suggest that Osthole may have a therapeutic application in the treatment of human lung cancer.

\section{Author details}

'Department of Respiratory Medicine, the Shengjing Hospital, China Medical University, Shenyang 110004, PR China. 'Department of Geriatrics, the Shengjing Hospital, China Medical University, Shenyang 110004, PR China.

\section{Authors' contributions}

XMX Conceived and the design of the study, carried out the cells studies and drafted the manuscript. YZ carried out the Western blotting studies. DQ participated in cells studies. TSJ performed the statistical analysis. SQL conceived of the study, and participated in its design and coordination. All authors read and approved the final manuscript.

\section{Competing interests}

The authors declare that they have no competing interests.

Received: 16 January 2011 Accepted: 29 March 2011

Published: 29 March 2011

\section{References}

1. Parkin DM, Bray F, Ferlay J, Pisani P: Global cancer statistics, 2002. CA Cancer J Clin 2005, 55:74-108.

2. Jemal A, Siegel R, Ward E, Hao Y, Xu J, Murray T, Thun MJ: Cancer statistics, 2008. CA Cancer J Clin 2008, 58:71-96.

3. Erridge SC, Moller H, Price A, Brewster D: International comparisons of survival from lung cancer: pitfalls and warnings. Nat Clin Pract Oncol 2007, 4:570-7.

4. Hsu SC, Ou CC, Chuang TC, Li JW, Lee YJ, Wang V, Liu JY, Chen CS, Lin SC, Kao MC: Ganoderma tsugae extract inhibits expression of epidermal growth factor receptor and angiogenesis in human epidermoid carcinoma cells: In vitro and in vivo. Cancer Lett 2009, 281:108-16.

5. SU CC, Lin YH: Tanshinone IIA down-regulates the protein expression of ErbB-2 and up-regulates TNF-alpha in colon cancer cells in vitro and in vivo. Int J Mol Med 2008, 22:847-51.

6. Carter BZ, Mak DH, Schober WD, Dietrich MF, Pinilla C, Vassilev LT, Reed JC, Andreeff M: Triptolide sensitizes AML cells to TRAIL-induced apoptosis via decrease of XIAP and p53-mediated increase of DR5. Blood 2008, 111:3742-50.

7. Guh JH, Yu SM, Ko FN, Wu TS, Teng CM: Antiproliferative effect in rat vascular smooth muscle cells by osthole, isolated from Angelica pubescens. Eur J Pharmacol 1996, 298:191-7.
8. Ko FN, Wu TS, Liou MJ, Huang TF, Teng CM: Vasorelaxation of rat thoracic aorta caused by osthole isolated from Angelica pubescens. Eur $\mathrm{J}$ Pharmacol 1992, 219:29-34.

9. Zimecki M, Artym J, Cisowski W, Mazol I, Wlodarczyk M, Glensk M: Immunomodulatory and anti-inflammatory activity of selected osthole derivatives. Z Naturforsch C 2009, 64:361-8.

10. Cai J, Yu B, Xu G, Wu J: Studies on the quality of fructus Cnidiicomparison of antibacterial action. Zhongguo Zhong Yao Za Zhi 1991, $16: 451-3,510$.

11. Matsuda $H$, Tomohiro $N$, Ido $Y$, Kubo M: Anti-allergic effects of cnidii monnieri fructus (dried fruits of Cnidium monnieri) and its major component, osthol. Biol Pharm Bull 2002, 25:809-12.

12. Okamoto T, Yoshida S, Kobayashi T, Okabe S: Inhibition of concanavalin Ainduced mice hepatitis by coumarin derivatives. Jpn J Pharmacol 2001, 85:95-7.

13. Yang $L L$, Wang $M C$, Chen $L G$, Wang CC: Cytotoxic activity of coumarins from the fruits of Cnidium monnieri on leukemia cell lines. Planta Med 2003, 69:1091-5.

14. Chou SY, Hsu CS, Wang KT, Wang MC, Wang CC: Antitumor effects of Osthol from Cnidium monnieri: an in vitro and in vivo study. Phytother Res 2007, 21:226-30.

15. Yang D, Gu T, Wang T, Tang Q, Ma C: Effects of osthole on migration and invasion in breast cancer cells. Biosci Biotechnol Biochem 2010, 74:1430-4.

16. Riviere C, Goossens L, Pommery N, Fourneau C, Delelis A, Henichart JP: Antiproliferative effects of isopentenylated coumarins isolated from Phellolophium madagascariense Baker. Nat Prod Res 2006, 20:909-16.

17. Okamoto T, Kobayashi T, Yoshida S: Chemical aspects of coumarin compounds for the prevention of hepatocellular carcinomas. Curr Med Chem Anticancer Agents 2005, 5:47-51.

18. Kauffmann-Zeh A, Rodriguez-Viciana P, Ulrich E, Gilbert C, Coffer P, Downward J, Evan G: Suppression of c-Myc-induced apoptosis by Ras signalling through PI(3)K and PKB. Nature 1997, 385:544-8.

19. Vivanco I, Sawyers CL: The phosphatidylinositol 3-Kinase AKT pathway in human cancer. Nat Rev Cancer 2002, 2:489-501.

20. Weir NM, Selvendiran K, Kutala VK, Tong L, Vishwanath S, Rajaram M, Tridandapani S, Anant S, Kuppusamy P: Curcumin induces G2/M arrest and apoptosis in cisplatin-resistant human ovarian cancer cells by modulating Akt and p38 MAPK. Cancer Biol Ther 2007, 6:178-84.

21. Katayama K, Fujita N, Tsuruo T: Akt/protein kinase B-dependent phosphorylation and inactivation of WEE1Hu promote cell cycle progression at G2/M transition. Mol Cell Biol 2005, 25:5725-37.

22. Asnaghi L, Calastretti A, Bevilacqua A, D'Agnano I, Gatti G, Canti G, Delia D, Capaccioli S, Nicolin A: Bcl-2 phosphorylation and apoptosis activated by damaged microtubules require mTOR and are regulated by Akt. Oncogene 2004, 23:5781-91.

23. Xavier CP, Lima CF, Preto A, Seruca R, Fernandes-Ferreira M, PereiraWilson C: Luteolin, quercetin and ursolic acid are potent inhibitors of proliferation and inducers of apoptosis in both KRAS and BRAF mutated human colorectal cancer cells. Cancer Lett 2009, 281:162-70.

24. Pu L, Amoscato AA, Bier ME, Lazo JS: Dual $G 1$ and $G 2$ phase inhibition by a novel, selective Cdc25 inhibitor 6-chloro-7-[corrected] (2-morpholin-4ylethylamino)-quinoline-5,8-dione. J Biol Chem 2002, 277:46877-85.

25. Chao Jl, Kuo PC, Hsu TS: Down-regulation of survivin in nitric oxideinduced cell growth inhibition and apoptosis of the human lung carcinoma cells. J Biol Chem 2004, 279:20267-76.

26. Wang Y, Ji P, Liu J, Broaddus RR, Xue F, Zhang W: Centrosome-associated regulators of the $\mathrm{G}(2) / \mathrm{M}$ checkpoint as targets for cancer therapy. $\mathrm{Mol}$ Cancer 2009, 8:8.

27. Dash BC, El-Deiry WS: Phosphorylation of p21 in G2/M promotes cyclin BCdc2 kinase activity. Mol Cell Biol 2005, 25:3364-87.

28. Yang CJ, Wang CS, Hung JY, Huang HW, Chia YC, Wang PH, Weng CF, Huang MS: Pyrogallol induces G2-M arrest in human lung cancer cells and inhibits tumor growth in an animal model. Lung Cancer 2009, 66:162-8.

29. Oltersdorf T, Elmore SW, Shoemaker AR, Armstrong RC, Augeri DJ, Belli BA, Bruncko M, Deckwerth TL, Dinges J, Hajduk PJ, Joseph MK, Kitada S, Korsmeyer SJ, Kunzer AR, Letai A, Li C, Mitten MJ, Nettesheim DG, Ng S, Nimmer PM, O'Connor JM, Oleksijew A, Petros AM, Reed JC, Shen W, Tahir SK, Thompson CB, Tomaselli KJ, Wang B, Wendt MD, Zhang H, Fesik SW, Rosenberg SH: An inhibitor of Bcl-2 family proteins induces regression of solid tumours. Nature 2005, 435:677-81. 
30. Thees S, Hubbard GB, Winckler J, Schultz C, Rami A: Specific alteration of the $\mathrm{Bax} / \mathrm{BCl} 2$ ratio and cytochrome $\mathrm{c}$ without execution of apoptosis in the hippocampus of aged baboons. Restor Neurol Neurosci 2005, 23:1-9.

31. Gupta S, Afaq F, Mukhtar H: Involvement of nuclear factor-kappa B, Bax and $\mathrm{BCl}-2$ in induction of cell cycle arrest and apoptosis by apigenin in human prostate carcinoma cells. Oncogene 2002, 21:3727-38.

32. Emi M, Kim R, Tanabe K, Uchida Y, Toge T: Targeted therapy against Bcl-2related proteins in breast cancer cells. Breast Cancer Res 2005, 7:R940-52.

33. Luo J, Manning BD, Cantley LC: Targeting the PI3K-Akt pathway in human cancer: rationale and promise. Cancer Cell 2003, 4:257-62.

doi:10.1186/1756-9966-30-33

Cite this article as: $\mathrm{Xu}$ et al:: Osthole induces G2/M arrest and apoptosis in lung cancer A549 cells by modulating PI3K/Akt pathway. Journal of

Experimental \& Clinical Cancer Research 2011 30:33.

Submit your next manuscript to BioMed Central and take full advantage of:

- Convenient online submission

- Thorough peer review

- No space constraints or color figure charges

- Immediate publication on acceptance

- Inclusion in PubMed, CAS, Scopus and Google Scholar

- Research which is freely available for redistribution

Submit your manuscript at www.biomedcentral.com/submit
Ciomed Central 